\title{
Detection of parvovirus B19 DNA in fetal tissues by in situ hybridisation and polymerase chain reaction
}

\author{
M M M SALIMANS, * F M van de RIJKE, A K RAAP, A M W van ELSACKER-NIELE* \\ The Departments of *Clinical Virology and Cytochemistry and Cytometry, University of Leiden, The \\ Netherlands
}

SUMMARY Attempts were made to detect human parvovirus B19-DNA by in situ hybridisation and the polymerase chain reaction in placental and fetal tissues from a case of intrauterine fetal death. In the in situ hybridisation experiments radioactive and non-radioactive (labelled with 2-acetylaminofluorene, AAF) DNA probes were used. B19-DNA was detectable in paraffin wax embedded fetal tissue from the liver, heart, lung, brain and thymus. The resolution with the AAF-labelled probes was higher than with the radiolabelled DNA. Parvovirus B19 DNA sequences were also detected in these tissues by an enzymatic in vitro amplification technique-the polymerase chain reaction. Amplification of a B19-DNA sequence before detection increases the rapidity and sensitivity of detection.

The rapid, specific, and sensitive analysis of parvovirus B19 in normal and diseased tissues using these techiques may contribute considerably to determining the role of this virus as a risk factor in the outcome of pregnancy.

Since the obervation by Cossart et al of a "new" virus in the sera of a number of blood donors, 'interest has increased in what is now known as the human parvovirus B19. ${ }^{2}$ This virus has an affinity for rapidly dividing tissues in general and erythroid progenitor cells in particular. The association between this virus and a defined clinical syndrome was first established by Serjeant $e t a \beta^{\beta}$ and by Pattison et $a l,{ }^{4}$ when they showed that B19 was the aetiological agent of severe aplastic crisis in children with sickle cell anaemia. Since then parvovirus B19 has been identified as the cause of erythema infectiosum (fifth disease of childhood $^{56}$ and has been associated with symptoms of arthritis and arthralgia. ${ }^{7-9}$

In the past few years infection with the human parvovirus B19 during pregnancy has been repeatedly associated with fetal death. ${ }^{10-15}$ Recent demonstration of B19 DNA in fetal tissue has indicated that the B19 virus can indeed cross the placenta. ${ }^{16-19}$

\section{Material and methods}

Tissue specimens from a case of intrauterine fetal death were examined. Pregnancy developed normally

Accepted for publication 3 November 1988 until the eighteenth week of gestation, when fetal movements stopped. Fetal death was confirmed by an ultrasound scan. Labour was induced and a macerated male fetus was born without visible defects or malformations. A maternal serum sample, drawn at about the time of fetal death, was shown to contain human parvovirus B19 specific IgM by radioimmunoassay (performed in the laboratory of Dr M J Anderson), indicating a recent B19 infection. ${ }^{17}$ The mother had not noticed any symptoms indicative of a B19 infection during pregnancy, but her son had been seen by the family doctor with a probable erythema infectiosum about three weeks before the death of the baby.

Fetal tissue specimens were routinely fixed (overnight fixation in 4\% formaldehyde in phosphate buffered saline, $\mathrm{pH} 7 \cdot 4$ ) and embedded in paraffin wax.

\section{LABELLING OF THE B19 DNA PROBE}

The parvovirus B19 DNA probe was kindly donated by Dr M J Anderson and consists of the Pstl fragment of parvovirus B19 DNA (700 base pairs) cloned into the pAT153 plasmid..$^{20}$ Control DNAs were either the pAT153 or pBR322 DNA without insert, or total herpes simplex virus DNA, or a set of M13 probes spanning 30 kilobase pairs of the human cytomegalovirus DNA. 
$\left[{ }^{35} \mathrm{~S}\right]$-labelling was done by nick translation, according to Rigby et a ${ }^{21}$ using $\left[\alpha^{-35} \mathrm{~S}\right]-\mathrm{dATP}(1170 \mathrm{ci} / \mathrm{mmol}$, NEN Dupont). Specific activities for all probes were about $3 \times 10^{8}$ disintegrations per minute $/ \mu \mathrm{g}$.

Acetylaminofluorene (AAF) labelling was done to a degree of modification of about $5 \%$ according to Landegent et $a .^{22}$ DNA probes were reduced to a fragment length of $200-500$ base pairs by sonication before AAF labelling. Quality control of AAF labelled probes was performed by non-radioactive filter hybridisation and spots of $1-5 \mathrm{pg}$ of unläbelled DNA could be detected.

IN SITU HYBRIDISATION

In situ hybridisations with AAF labelled probes were done essentially as described by Raap et al. ${ }^{23}$ Briefly, sections $(5 \mu \mathrm{m})$ of paraffin wax embedded fetal tissues were bound to gelatin-chrome-alum coated glass slides, which were activated before use with $2.5 \%$ glutaraldehyde in phosphate buffered saline (PBS) for 15 minutes. After baking at $52^{\circ} \mathrm{C}$ (one hour) and deparaffinisation in xylene, endogenous peroxidase activity was inactivated with $1 \% \mathrm{H}_{2} \mathrm{O}_{2}$ in methanol and aldehyde groups with $1 \%$ hydroxyl ammonium chloride in PBS, $\mathrm{pH} 7 \cdot 4$. The sections were then treated with proteinase $\mathrm{K}(15 \mu \mathrm{g} / \mathrm{ml})$ for 30 minutes at $37^{\circ} \mathrm{C}$ in $20 \mathrm{mM}$ Tris- $\mathrm{HCl}, 2 \mathrm{mM} \mathrm{CaCl}, \mathrm{pH} 7 \cdot 4$. The hybridisation solution contained $5 \mathrm{ng} / \mu \mathrm{l}$ AAF-DNA, $100 \mathrm{ng} / \mu \mathrm{l}$ sheared salmon sperm DNA, 0.02\% bovine serum albumin (BSA), 0.02\% Ficoll-400, 0.02\% polyvinylpyrrolidone, $50 \%$ deionised formamide, $50 \mathrm{mM}$ phosphate, $4 \times \operatorname{SSC}(0.6 \mathrm{M} \mathrm{NaCl}, 0.06 \mathrm{M}$ sodium citrate at $\mathrm{pH} 6.8$ ), and was denatured together with the tissue sections at $90^{\circ} \mathrm{C}$ for 10 minutes, after which in situ hybridisation was allowed to proceed for 16 hours at $37^{\circ} \mathrm{C}$. Post-hybridisation washings were: two times 10 minutes $2 \times$ SSC, $0.1 \%$ sodium dodecyl sulphate (SDS) at room temperature; 10 minutes $0.1 \times$ SSC, $0.1 \%$ SDS at room temperature; and 10 minutes $0 \cdot 1 \times \mathrm{SSC}, 0 \cdot 1 \% \mathrm{SDS}$ at $60^{\circ} \mathrm{C}$. After a brief wash with PBS immunocytochemical detection was accomplished by an indirect immunoperoxidase technique using a mouse monoclonal anti-AAF antibody (1/500 in PBS, 0.05\% Tween-20, 2\% normal swine serum, 45 minutes at $37^{\circ} \mathrm{C}$ ) and horse radish peroxidase conjugated swine antimouse immunoglobulin (1:100). Peroxidase was visualised with $0.05 \%$ diaminobenzidine (DAB), $0.05 \% \mathrm{H}_{2} \mathrm{O}_{2}, 50 \mathrm{mM}$ Tris- $\mathrm{HCl}, 0.01 \mathrm{M}$ imidazole, $\mathrm{pH} 7 \cdot 6$. Sections were counterstained with haemotoxylin and eosin.

In situ hybridisation with $\left.{ }^{35} \mathrm{~S}\right]$-labelled probes was carried out essentially in the same way, except for the detection: after the post-hybridisation washings the sections were dehydrated and dipped in a NBT-2 emulsion (Kodak) and exposed for two to six days.
POLYMERASE CHAIN REACTION (PCR)

DNA amplification was based on the procedure described by Saiki et al with the thermostable DNA polymerase isolated from Thermus aquaticus. ${ }^{24}$ Following the technique described by Shibata $e t$ al, who reported the use of the PCR for the detection of human papillomavirus in paraffin wax embedded tissue ${ }^{25}$ we applied the PCR technique previously described for the human parvovirus $\mathrm{B} 19^{26}$ for the paraffin wax embedded fetal tissues of this case. Briefly, formalin fixed tissue sections $(5 \mu \mathrm{m})$ were deparaffinised by three washings with xylene and one with methanol. After evaporation of the methanol $50 \mu \mathrm{l} \mathrm{H}_{2} \mathrm{O}$ was added and the reaction phial was incubated for 10 minutes at $100^{\circ} \mathrm{C}$. The PCR mix $(50 \mu \mathrm{l})$ was then added. Final concentrations were: $10 \mathrm{mM}$ Tris- $\mathrm{HCl}$ (pH 9.6); $10 \mathrm{mM} \mathrm{MgCl}_{2} ; 0.2 \mathrm{mg} / \mathrm{ml} \mathrm{BSA} ; 50 \mathrm{mM}$ $\mathrm{NaCl} ; 1 \mathrm{mM}$ dATP; $1 \mathrm{mM}$ dCTP; $1 \mathrm{mM}$ dTTP; $1 \mathrm{mM}$ dGTP; $1 \mu \mathrm{g}$ of the primers for both parvovirus B19DNA strands (called B19-1 and B19-26) and 1 U Taq DNA polymerase. Thirty two incubation cycles were carried out for one minute at $95^{\circ} \mathrm{C}$ followed by three minutes at $65^{\circ} \mathrm{C}$. Finally, $10 \mu \mathrm{l}$ samples were taken and analysed on a $2 \%$ agarose gel by electrophoresis in TBE buffer $\left(80 \mathrm{mM}\right.$ Tris/borate, $1 \mathrm{mM}$ edetic acid $\left.^{27}\right)$ containing $0.5 \mu \mathrm{g} / \mathrm{ml}$ ethidium-bromide.

\section{Results}

Fig 1 shows some typical results obtained with various tissues using the $\left.{ }^{35} \mathrm{~S}\right]$-labelled parvovirus B19 DNA probes after 48 hours of autoradiographic exposure. All tissues available (thymus, liver, brain, heart and lung) were positive, but the number of positive cells varied in each organ. A dot spot hybridisation with DNA isolated from placental tissue was also positive (result not shown). Hybridisations with the control probe gave negative results.

Fig 2 shows the results obtained with the nonradioactive in situ hybridisation technique, using AAF. These results were obtained within a few hours after the in situ hybridisation and were similar to the radioactive results in terms of number of positive cells. The AAF technique obviously gives better resolution. In the liver endogenous iron pigment (haemosiderin) was present. This may resemble the brown DAB immunoperoxidase product and thus may complicate microscopic evaluation. By using Perls's Prussian blue staining technique this pigment is stained blue and can be clearly differentiated from specific in situ hybridisation signals.

The polymerase chain reaction was carried out on the paraffin wax embedded tissues to establish the presence of B19 DNA (without a preceding DNA isolation procedure). The results are given in fig 3 . After amplification the reaction mixtures were 

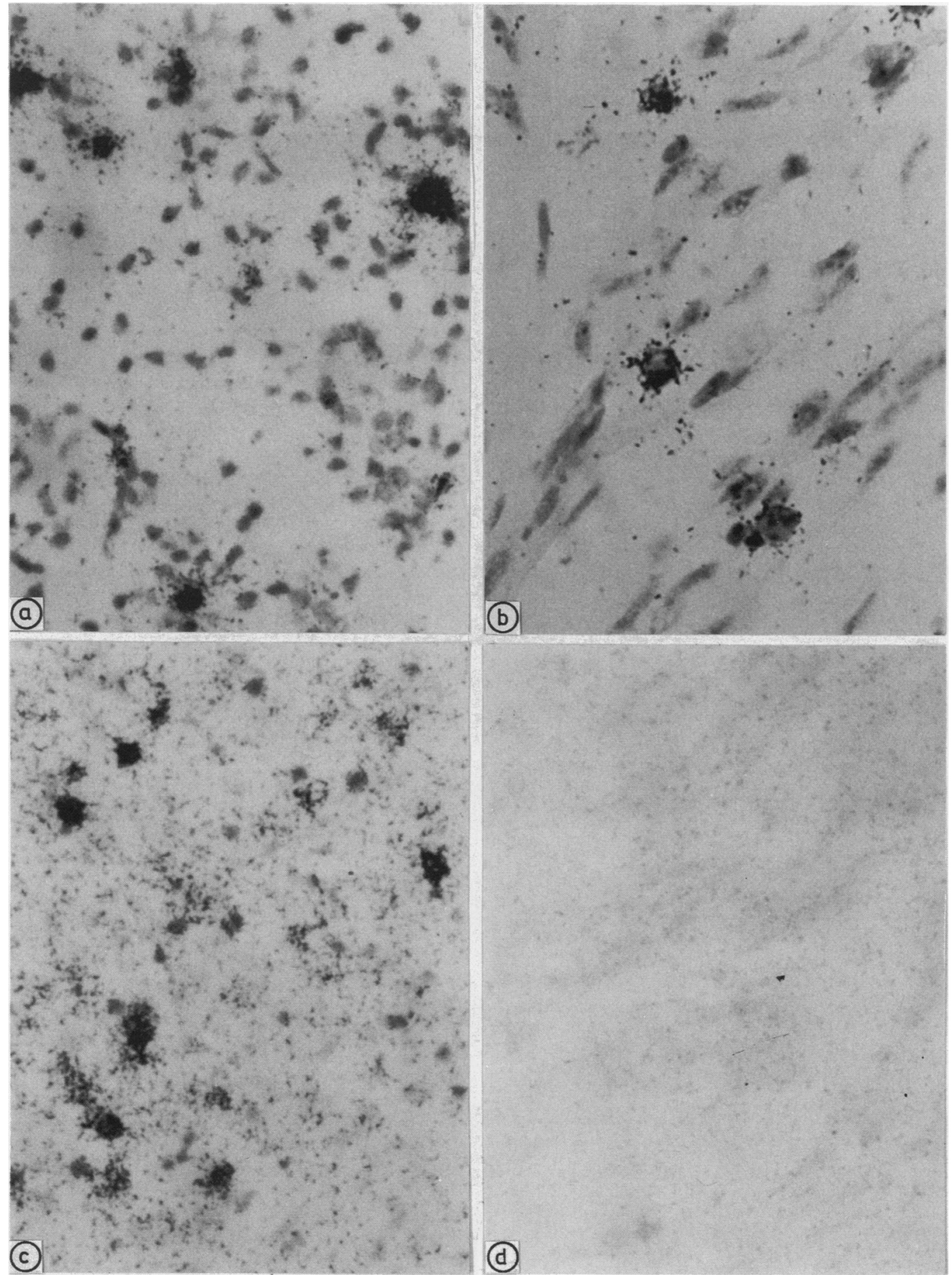

Fig 1 In situ hybridisation of fetal tissues with radioactively labelled parvovirus DNA probe.

DNA was labelled by nick translation. Numerous positive cells can be detected in several tissues: (a) lung; (b) heart; (c) liver; (d) control experiment with plasmid DNA without B19-DNA insert (heart tissue). 

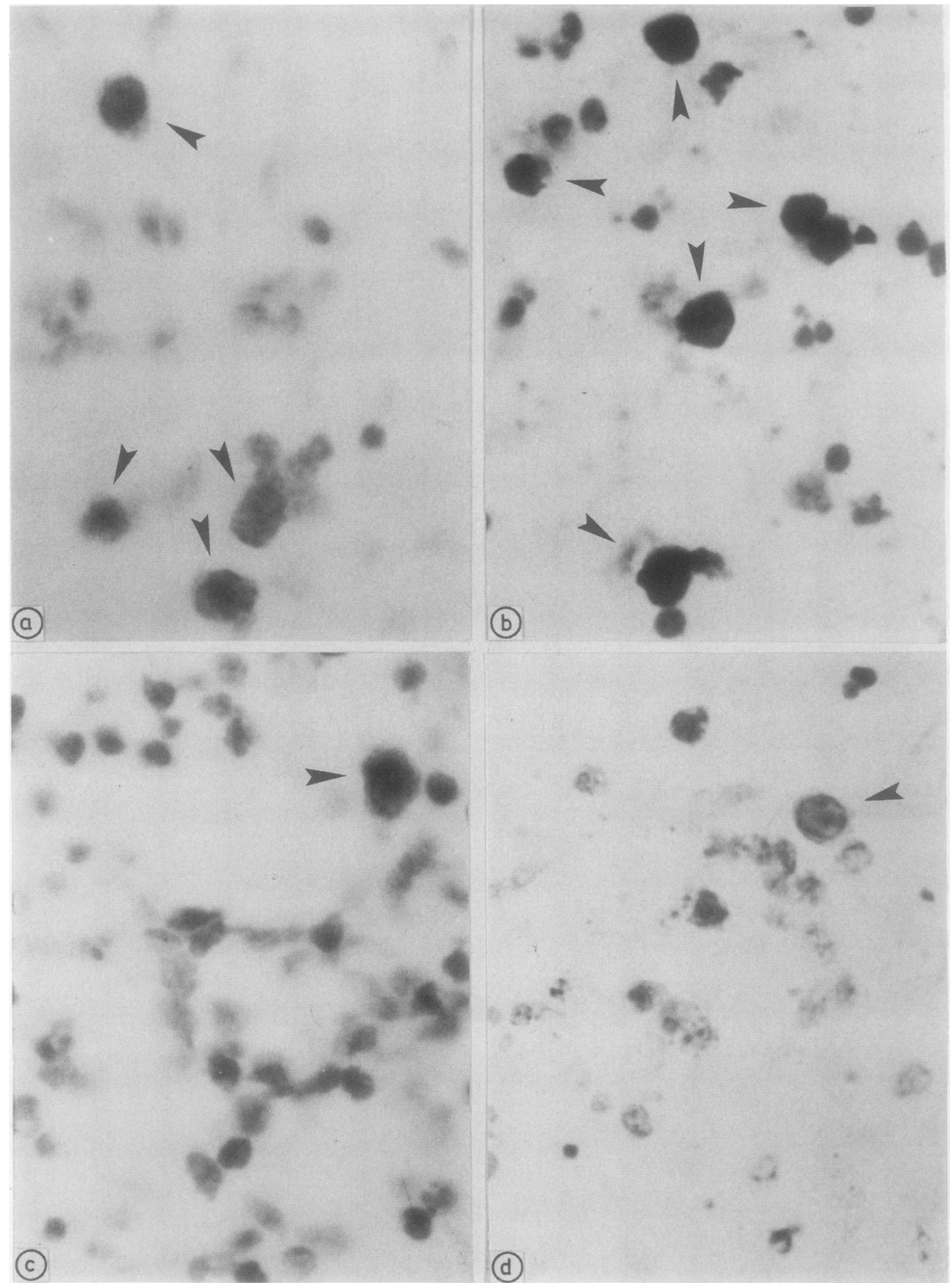

(b)

Fig 2 In situ hybridisation with an AAF labelled B19-DNA probe. Cells containing parvovirus B19-DNA were recognised by an indirect immunoperoxidase technique with anti-AAF monoclonal antibodies. Positive cells were detectable in several fetal tissues: (a) lung; (b) heart; (c) thymus (arrows). Panel (d) indicates the presence of relatively large cells with inclusion bodies in liver tissue (often observed in parvovirus B19 infections, arrow). 


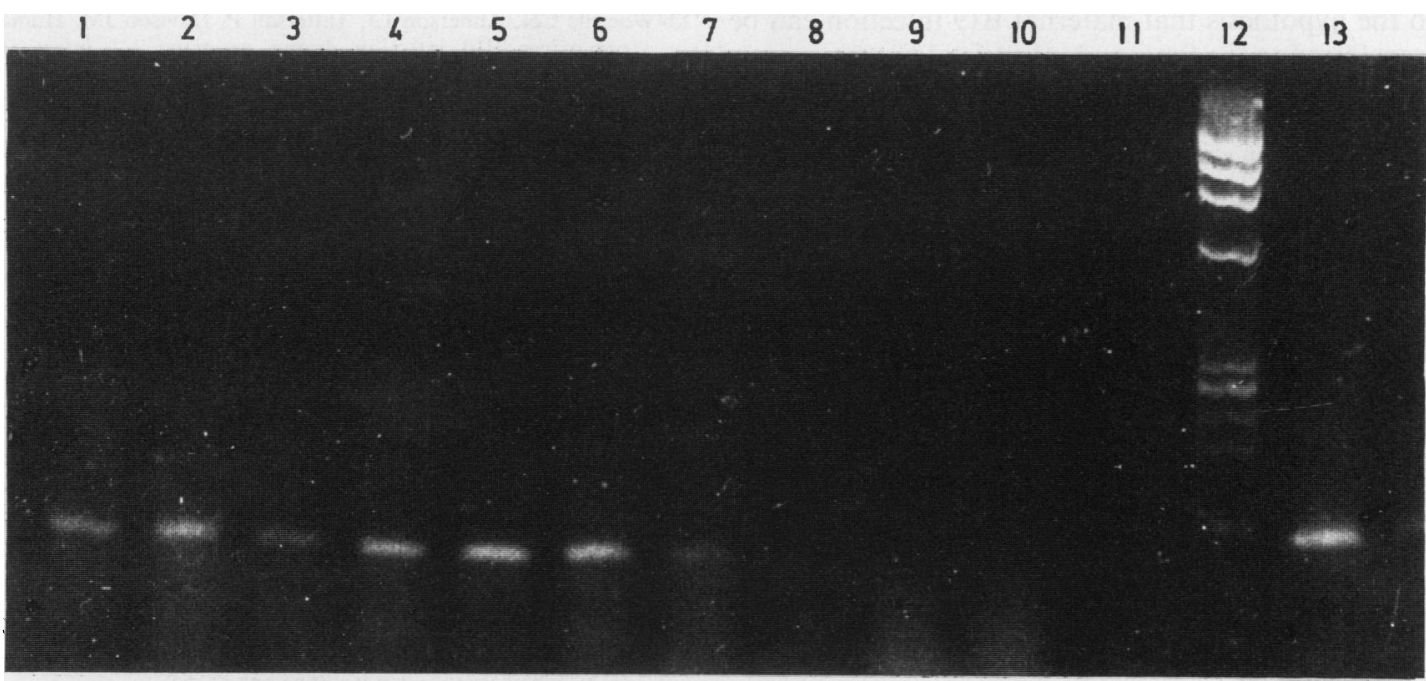

Fig 3 Detection of parvovirus B19-DNA in tissue sections by PCR. Several fetal tissue sections were analysed on an agarose gel stained with ethidium-bromide for the presence of the amplified B19-DNA specific band (104 base pairs): (1) and (7) thymus; (2) liver; (3) brain; (4) and (5) heart; (6) lung; (8) placenta; (9) and (10) fetal liver from a B19 seronegative pregnancy; (12) DNA markers (\$X174 RF DNA/Hae III Fragments); (13) 100 pg plasmid DNA: pAT153 with the Pstlfragment of $B 19-D N A$.

analysed by electrophoresis on agarose. Without hybridisation and autoradiography ethidium-bromide staining indicated the presence of a 104 base pair band specific for the presence of B19 DNA. ${ }^{26}$ Paraffin wax embedded tissues not expected to contain parvovirus B19, such as fetal liver tissue from a fetus from a B19 seronegative pregnancy, did not show evidence of amplification with the B19 PCR.

\section{Discussion}

Interest in the application of in situ hybridisation techniques for the diagnosis of viral infections has grown considerably, particularly for those viruses which cannot be diagnosed by isolation procedures. The possibility of using a non-radioactive label makes this technique more attractive and practicable for most of the clinical laboratories. 22232829 Several features of the AAF labelling technique described here make it very valuable for use in diagnostic procedures $^{2223} 30$ and some major advantages over the use of radioactive probes are as follows: the detection method is much less time consuming and does not require special equipment; the resolution is much better; the sensitivity is similar to that with radioactive labelled DNA ${ }^{30}$; and both DNA and RNA, single as well as double stranded, can be modified reproducibly in small and large quantities and stored for long periods of time (more than two years).

When Saiki et al described a new method for enzymatically amplifying specific target DNA sequences, ${ }^{24}$ the possible use for viral diagnosis was mentioned. Recently we described a method for the detection of parvovirus B19 DNA ${ }^{26}$ and in this study present a broader application for the detection of this virus in fixed tissues. The relative ease with which the paraffin wax embedded tissues can be studied using the PCR is clear. Tissues containing cells positive in in situ hybridisation experiments were also positive in the PCR; tissues expected to be negative for B19 did not show a B19 specific DNA band. The only discrepancy was placental tissue which was slightly positive in the in situ hybridisation test (one or two positive cells in each section) and was negative in the PCR. This was probably due to sampling error. The major advantages of the PCR over conventional dot-blot hybridisation tests are that: the technique does not require radioactively labelled agents; and is rapid, simple, and very sensitive, but it does not give morphological information.

The histopathological indications of intrauterine B19 infection in this case were perivascular infiltrates in the placenta, nuclear inclusion bodies in fetal erythroid cells and macrophages that presumably are characteristics of B19 infections, ${ }^{1231-33}$ and signs of massive fetal haemolysis before death. Our in situ hybridisation and PCR studies confirmed fetal B19 infection in this case by the detection of cells containing B19 DNA in fetal liver, heart, lung and (to a lesser extent) thymus and brain. These results lend support 
to the hypothesis that maternal B19 infection can be transferred to the fetus and infect fetal tissues.

In summary, our results show the feasibility of diagnosing viral infections on the basis of the nucleic acid component with in situ hybridisation and PCR. PCR is technically more simple than in situ hybridisation and is probably also more sensitive. In situ hybridisation, however, also gives histopathological information.

The rapid and sensitive detection of B19 DNA in normal and pathological tissues using the techniques described here may contribute substantially to establishing the role of parvovirus B19 infection as a risk factor in the outcome of pregnancy.

We thank C S Brown for helpful criticism.

\section{References}

1 Cossart YE, Field AM, Cant B, Widdows D. Parvovirus-like particles in human sera. Lancet 1975;i:72-3.

2 Anderson MJ, Pattison JR. The human parvovirus: a brief review. Arch Virol 1984;82:137-48.

3 Serjeant GR, Mason K, Topley JM, et al. Outbreak of aplastic crisis in sickle cell anaemia associated with parvovirus-like agent. Lancet 1981;i:595-7.

4 Pattison JR, Jones SE, Hodgson J, et al. Parvovirus infections and hypoplastic crisis in sickle cell anaemia. Lancet 1981;i:664.

5 Anderson MJ, Jones SE, Fisher-Hoch SP, et al. The human parvovirus, the cause of erythema infectiosum (fifth disease)? Lancet 1983;i:1378.
15 Woernle CH, Anderson LJ, Tattersall P, Davison JM. Human parvovirus B19 infection during pregnancy. J Infect Dis 1987;156:17-20.

16 Clewley JP, Cohen BJ, Field AM. Detection of parvovirus B19 DNA, antigen and particles in the human fetus. J Med Virol 1987;23:367-76.

17 Van Elsacker-Niele AMW, Salimans MMM, Weiland HT, Vermey-Keers C, Anderson MJ, Versteeg J. Fetal pathology in human parvovirus B19 infection. Br J Obstet Gynecol (in press).

18 Franciosi RA, Tattersall P. Fetal infection with human parvovirus B19. Hum Pathol 1988;19:489-91.

19 Brown T, Anand A, Richie LD, Clewley JP, Reid TMS. Intrauterine infection with human parvovirus. Lancet 1984;i:448-9.

20 Anderson MJ, Jones SE, Minson AC. Diagnosis of human parvovirus infection by dot-blot hybridisation using cloned viral DNA. J Med Virol 1985;15:163-72.

21 Rigby PWJ, Dieckmann M, Rhodes C, Berg P. Labelling deoxyribuonucleic acid to high specific activity in vitro by nicktranslation with DNA polymerase I. J Mol Biol 1977;113: 237-51.

22 Landegent JE, Jansen in de Wal N, Baan RA, Hoeijmakers JHJ, van der Ploeg M. 2-Acetylaminofluorene-modified probes for the indirect hybridocytochemical detection of specific nucleic acid sequences. Exp Cell Res 1984;153:61-72.

23 Raap AK, Geelen JL, van der Meer JWM, van de Rijke FM, van den Boogaart P, van der Ploeg $M$. Non-radioactive in situ hybridization for the detection of cytomegalovirus infections. Histochem J 1988;88:367-73.

24 Saiki RK, Gelfland DH, Stoffel S, et al. Primer-directed enzymatic amplification of DNA with a thermostable DNA polymerase. Science 1988;239:487-91.

25 Shibata DK, Arnheim N, Martin WJ. Detection of human papilloma virus in paraffin-embedded tissue using the polymerase chain reaction. $J$ Exp Med 1988;167:225-30.

26 Salimans MMM, Holsappel S, van de Rijke FM, Jiwa NM, Raap AK, Weiland HT. Rapid detection of human parvovirus B19 DNA by dot-hybridisation and the polymerase chain reaction. $J$ Viral Mothads 1989.22 19-78 